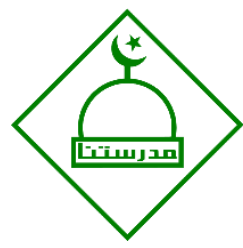

\title{
EVALUASI KINERJA GURU IPA
}

\author{
Rahmat Rizal \\ Universitas Siliwangi, Tasikmalaya, Indonesia \\ rahmatrizal@unsil.ac.id
}

\begin{abstract}
The quality assurance of science education is closely related to teacher performance. When science teachers do good performance, the implementation of science learning as the core business of science education can be said to be of high quality. The quality of science teacher services includes the process and learning outcomes. Performance is a variable that is used as a measure of the level of achievement of teacher assignments. Teachers are said to have good performance when they can complete their tasks and achieve teacher performance indicators. The science teaching performance indicators are stated in the professional competency standards of science teachers mandated by Minister of National Education No. 16 of 2007. The reality in the field of various studies shows that the performance of science teaching is still facing the problem, among others teachers have not been able to implement science process skills and have not been able to develop thinking skills in science learning. Evaluating the performance of science teachers requires the development of teacher performance evaluation instruments by considering the role of teachers in learning and based on the standards of developing instruments formulated by experts including Stronge. Teaching audits are conducted as an effort to convince the public about the suitability of the performance of science teachers in Indonesia with predetermined science education standards. The role of the Teaching audit in the education quality assurance system is not only to improve quality but rather focus on decision making so that there are legal consequences that are generated.
\end{abstract}

Keywords: science learning, instrument performance, teaching audit

\begin{abstract}
ABSTRAK
Penjaminan mutu pendidikan IPA erat kaitannya dengan kinerja guru. Ketika guru IPA melakukan kinerja yang baik maka pelaksanaan pembelajaran IPA sebagai core business Pendidikan IPA dapat dikatakan bermutu. Mutu layanan guru IPA meliputi proses dan hasil pembelajaran. Kinerja merupakan variabel yang digunakan sebagai ukuran tingkat ketercapaian tugas guru. Guru dikatakan memiliki kinerja yang baik manakala dapat menyelesaikan tugas-tugasnya maupun mencapai indikator kinerja guru. Indikator kinerja pengajaran IPA tercantum dalam standar kompetensi professional guru IPA yang diamanatkan Permendiknas No. 16 tahun 2007. Kenyataan di lapangan berbagai studi menunjukkan kinerja mengajar IPA masih menghaapi masalah diantaranya guru belum mampu mengimplementasikan keterampilan proses sains dan belum mampu mengembangkan keterampilan berpikir dalam pembelajaran IPA. Mengevaluasi kinerja guru IPA diperlukan pengembangan instrumen evaluasi kinerja guru dengan mempertimbangkan peran guru dalam pembelajaran dan berdasarkan pada standar pengembangan instrument yang dirumuskan oleh ahli diantaranya Stronge Teacbing audit dilakukan sebagai upaya untuk meyakinkan publik tentang kesesuaian kinerja guru IPA di Indonesia dengan standar pendidikan IPA yang telah ditentukan. Peran Teaching audit dalam sistem penjaminan mutu pendidikan bukan hanya untuk meningkatkan kualitas melainkan lebih menitikberatkan pada pengambilan keputusan sehingga terdapat konsekuensi legal yang dihasilkan.
\end{abstract}

Kata-kata kunci : pembelajaran IPA, instrumen kinerja, teaching audit

\section{PENDAHULUAN}

Pendidikan IPA di Indonesia saat ini dipandang memiliki mutu yang masih tergolong rendah. Berdasarkan studi yang dilakukan oleh Program of International Student Assessment (PISA) pada tahun 2012, Indonesia berada pada peringkat 64 dari 65 negara (OECD, 2012). Kenyataan ini tentunya menjadi 
tantangan tersendiri bagi semua stakeholder yang terlibat dalam penyelenggaraan Pendidikan IPA di Indonesia untuk terus berupaya meningkatkan mutu Pendidikan IPA.

Salah satu yang diyakini memiliki andil besar dalam tinggi rendahnya mutu pendidikan IPA adalah guru IPA. Guru merupakan fasilitator yang secara langsung memegang pelaksanaan core bussines pendidikan IPA yaitu pembelajaran IPA di kelas. Di sini gurulah yang mengetahui, menyaksikan sekaligus melaksanakan what is going on in the class room yang secara spesifik dapat dikatakan what is going on in science classroom. Dalam hal ini di tangan gurulah terletak keterlaksanaan pembelajaran IPA yang sesuai dengan key learning areas yang digunakan di Indonesia dimana proses pembelajaran yang dilakukan memiliki fungsi untuk membimbing siswa menguasai pengetahuan melalui proses penemuan oleh siswa sendiri melalui pengalaman-pengalaman selama pembelajaran berlangsung sehingga menghasilkan pengetahuan yang bermakna (Rizal, 2018)

Pemerintah secara khusus memberikan perhatian besar terhadap profesi guru Dalam rangka meningkatkan kualitas guru dengan berpedoman pada Undang-Undang No.14 Tahun 2005 tentang guru dan dosen yang telah mengamanatkan perlindungan terhadap guru menyangkut ranah perlindungan hukum, perlindungan profesi, serta perlindungan keselamatan dan kesehatan kerja. Namun, perhatian terhadap profesi guru tersebut saat ini masih dimaknai sebatas peningkatan kesejahteraan melalui pemberian tunjangan profesi. Pengembangan profesi guru sendiri yang jauh tidak kalah pentingnya masih perlu dibenahi.

Seorang guru IPA yang profesional hendaknya dapat memfasilitasi siswa untuk memiliki literasi sains sehingga dapat menghadapi era globalisasi yang dipenuhi produk-produk dan isu saintifik, mengembangkan keterampilan proses sains agar dapat menciptakan pembelajaran yang bermakna serta melatih keterampilan berpikir untuk menjawab tantangan di masa depan (Rizal, 2019). Guru IPA juga memiliki tanggung jawab profesional terhadap pengembangan profesinya dengan membekali diri dengan sejumlah kompetensi dalam menggunakan teknologi yang dapat digunakan dalam mengefektifkan kegiatan pembelajaran (Rizal, 2019).

Peningkatan kualitas guru tidak dapat dilakukan secara instant melainkan membutuhkan proses yang cukup panjang dan berkesinambungan. Mengingat status guru dipandang sebagai profesi, diperlukan suatu penjaminan mutu yang memberikan garansi terkait pelayanan guru sebagai pendidik professional. Fenomena pengembangan sprofessional guru ini memperoleh perhatian yang lebih besar di Indonesia sejak tahun 2007 dimana program sertifikasi dan pendidikan profesi guru dalam jabatan mulai dilaksanakan yang secara operasional dilaksanakan dalam bentuk Pendidikan dan Latihan Profesi Guru (PLPG) dan Pendidikan Profesi Guru (PPG).

Guru memiliki posisi strategis dalam penjaminan mutu khususnya ketika menyelenggarakan pembelajaran di kelas. Peran guru dalam penjaminan mutu pendidikan berkaitan erat dengan kompetensi 
yang dimiliki guru tersebut. Namun, kompetensi guru IPA di Indonesia diyakini masih perlu untuk ditingkatkan. Secara global, rekapitulasi nasional hasil Uji Kompetensi Guru (UKG) tahun 2015 yang mengujikan kompetensi pedagogik dan kompetensi profesional menunjukkan nilai rata-rata 53,02. Nilai ini masih belum memenuhi Standar Kompetensi Minimum (SKM) yang telah ditetapkan yaitu 5,50. Kemudian dari 34 provinsi di Indonesia, hanya tujuh provinsi yang nilai rata-rata UKGnya melewati nilai SKM yaitu DI Yogyakarta (62,58), Jawa Tengah (59,10), DKI Jakarta $(58,44)$, Jawa Timur $(56,73)$, Bali (56,13), Bangka Belitung (55,13), dan Jawa Barat (55,06) (Kemendikbud, 2015). Hafi (2015) menyampaikan data lokal bahwa dari 32.186 guru sekolah negeri di DKI Jakarta yang mengikuti UKG, 22 ribu guru hanya mampu mencapai level nol sampai lima dilihat dari skala nol sampai sepuluh. Padahal dalam jumlah tersebut terdapat guru yang sudah melakukan sertifikasi dan mendapatkan Tunjangan Profesi Guru (TPG).

Prestasi yang dicapai guru dalam melaksanakan tugas kompetensi guru tersebut tercermin melalui kinerja. Kinerja merupakan prestasi yang dicapai oleh seseorang dalam melaksanakan tugasnya atau pekerjaannya selama periode tertentu sesuai standard dan kriteria yang telah ditetapkan untuk pekerjaan tersebut. Kinerja guru IPA perlu mendapat perhatian yang besar untuk meningkatkan dan menjamin mutu pendidikan IPA di Indonesia sehingga diperlukan adanya evaluasi terhadap kinerja guru IPA. Kinerja guru, termasuk guru IPA, sering dipersoalkan ketika memperbicangkan masalah peningkatan mutu pendidikan. Guru IPA memiliki peranan yang sangat penting dalam menentukan keberhasilan pendidikan IPA. Guru IPA yang profesional diharapkan menghasilkan lulusan yang berkualitas. Profesionalisme guru IPA sebagai ujung tombak di dalam implementasi kurikulum IPA di sekolah, harus mendapat perhatian. Berdasarkan uraian tersebut di atas, pemahaman yang baik tentang kinerja guru sangatlah penting dimiliki oleh pendidik dan tenaga kependidikan sehingga segala aktivitas akan diupayakan untuk mencapainya.

\section{METODE PENELITIAN}

Metode penelitian pada naskah artikel menjelaskan jenis penelitian, subjek dan objek penelitian, waktu dan lokasi penelitian, instrumen penelitian, cara pengambilan sampel, pengumpulan data, dan analisis data.

Penelitian ini merupakan penelitian kualitatif deskriptif dengan menggunakan metode studi pustaka (library research) yang menjadi jurnal-jurnal, buku-buku, dan referensi terpercaya lainnya sebagai subjek utama. Penelitian ini menghasilkan informasi data deskripstif dalam bentuk teks berkaitan dengan evaluasi kinerja guru IPA yang disajikan secara jelas, objektif, sistematis, dan kritis.

Sumber data dalam penelitian ini terdiri atas sumber data penelitian primer dan sumber data penelitian sekunder. Sumber data primer merupakan referensi utama yang dijadikan acuan dalam 
penelitian. Sumber data primer ini berupa buku-buku dan jurnal-jurnal yang memiliki kredibilitas tinggi. Sumber data penelitian sekunder merupakan referensi data yang memberikan dukungan terhadap sejumlah data dan informasi yang diperoleh dari sumber data penelitian primer. Sumber data penelitian sekunder ini berupa data yang diperoleh dari web site pemerintah dan juga beberapa dokumen-dokumen resmi yang diterbitkan dari pemerintah berkaitan dengan evaluasi kinerja guru.

Analisis data yang dilakukan dalam penelitian ini diawali dengan proses pemilahan data berdasarkan kredibilitas data yang disajikan. Teknik analisis data ang digunakan adalah teknik analisis isi (content anlysis) dalam bentuk analisis ilmiah tentang isi pesan dari data yang disajikan.

\section{HASIL DAN PEMBAHASAN}

\section{A. Konsep Kinerja Mengajar IPA}

Kinerja merupakan suatu hasil kerja yang dicapai seseorang dalam melaksanakan tugas-tugas yang dibebankan kepadanya yang didasarkan atas kecakapan, pengalaman, kesungguhan, dan waktu (Hasibuan, 2003:34). Bacal (2001) menjelaskan kinerja secara khusus pada profesi guru sebagai proses komunikasi yang berlangsung terus-menerus, yang dilaksanakan secara kemitraan, antara seorang guru dan siswa, guru dan kepala sekolah yang akan mendukung percepatan pemahaman siswa terhadap materi ajar. Dengan demikian kinerja guru dapat dipahami sebagai persepsi guru terhadap prestasi kerja guru yang berkaitan dengan kualitas kerja, tanggung jawab, kejujuran, kerjasama, dan prakarsa.

Kinerja seseorang terdiri atas empat dimensi yaitu kinerja tugas (task performance), kinerja kontekstual (contecxtualperformance), kinerja adaptif (adaptive performance), dan sikap kerja tidak produktif (counterproductive behaviour). Tugas kinerja terdiri dari menyelesaikan tugas pekerjaan, kuantitas kerja, kualitas kerja, keterampilan dalam bekerja, pengetahuan atas pekerjaan, perencanaan dan organisasi, adminstrasi, komunikasi lisan dan tulisan, pemecahan masalah, dan pengotrolan sumber daya. Tugas kontekstual terdiri dari: tugas tambahan, usaha, inisiatif, antusiasme, perhatian terhadap tanggung jawab, motivasi, dedikasi, pro-aktif, kreativitas, kerja sama, komunikasi yang efektif, dan hubungan personal. Kinerja adaptif terdiri dari: ide yang inovatif, penyesuaian tujuan dan rencana dengan situasi, fleksibel dan berpikiran terbuka, pemahaman terhadap budaya orang lain, bersikap tenang, dan bertindak dengan tepat. Sikap kerja tidak produktif meliputi: waktu istirahat yang terlalu lama, ketidak hadiran, mengerjakan tugas dengan tidak tepat, mengucilkan rekan kerja, berdebat dengan rekan kerja, dan mengabaikan keamanan dalam kerja. (Koopmans, et al, 2011).

Pada konteks manajemen organisasi kinerja merupakan suatu wujud perilaku seseorang atau organisasi dengan orientasi prestasi. Kinerja seseorang dipengaruhi oleh beberapa faktor seperti: ability, capacity, held, incentive, environment dan validity (Notoa tmojo, 1992). Adapun ukuran kinerja menurut Mitchell (1989) dapat dilihat dari lima hal, yaitu: 
1. Quality of work - kualitas hasil kerja

2. Promptness - ketepatan waktu menyelesaikan pekerjaan

3. Initiative - prakarsa dalam menyelesaikan pekerjaan

4. Capability - kemampuan menyelesaikan pekerjaan

5. Comunication - kemampuan membina kerjasama dengan pihak lain.

Kinerja dari seseorang dapat ditunjukkan dengan bagaimana seseorang dalam melaksanakan pekerjaannya. Bagi guru IPA, kinerja dapat ditinjau berdasarkan tugas dan tanggung jawab pekerjaannya dalam mengajarkan IPA. Usman (1994:3) mengemukakan mengajar pada prinsipnya adalah membimbing siswa dalam kegiatan belajar mengajar atau mengandung pengertian bahwa mengajar merupakan suatu usaha mengorganisasi lingkungan dalam hubungannya dengan anak didik dan bahan pengajaran yang menimbulkan terjadinya proses belajar. Hamalik (2001:44-53) mengemukakan, mengajar dapat diartikan sebagai (1) menyampaikan pengetahuan kepada siswa, (2) mewariskan kebudayaan kepada generasi muda, (3) usaha mengorganisasi lingkungan sehingga menciptakan kondisi belajar bagi siswa, (4) memberikan bimbingan belajar kepada murid, (5) kegiatan mempersiapkan siswa untuk menjadi warga negara yang baik, (6) suatu proses membantu siswa menghadapi kehidupan masyarakat sehari-hari.

Dalam mengajarkan IPA, guru hendaknya memperhatikan hakikat IPA itu sendiri dimana IPA merupakan pengetahuan tentang epistemologi (metode) dari sains, proses terjadinya sains, atau nilai dan keyakinan yang melekat untuk mengembangkan sains (Khalick dkk,2008). Pengajaran IPA menekankan pada pengalaman langsung siswa dalam memahami fenomena alam yang terjadi di sekitar mereka untuk menghasilkan pengetahuan yang bermakna dan melatihkan berbagai kemampuan dan keterampilan (Direktorat Tenaga Kependidikan, 2008)

Praktik pendidikan IPA di sekolah tidak terlepas dari pentingnya quality insuranse terhadap peserta didik. Dalam konteks quality insurance, hendaknya sekolah dapat memberikan perlindungan terhadap peserta didik dari pelayanan pendidikan yang tidak bermutu (Satori, 2012). Mutu layanan pendidikan IPA tidak terlepas dari profesionalisme dan kompetensi yang dimiliki seorang guru IPA.

Kompetensi profesional yang harus dimiliki guru IPA dalam konteks praktis telah dipetakan National Science Teaching Association (1999) dimana praktik profesional guru IPA memerlukan pengetahuan dan nilai tentang: (1) Konteks IPA, (2) Konteks sosial pengajaran IPA, (3) Asesmen, (4) Pengajaran melalui inkuiri untuk pemahaman dan aplikasi, (5) Kurikulum IPA, (6) Pengetahuan konten, dan (7) Pengetahuan pedagogi.

Peraturan menteri pendidikan nasional No. 16 tahun 2007 telah menetapkan standar kompetensi yang harus dimiliki oleh seorang guru yang terdiri dari empat jenis kompetensi yang terdiri dari kompetensi kepribadian, kompetensi paedagogik, kompetensi profesional, dan kompetensi sosial. 
Kompetensi kepribadian erat kaitannya dengan sikap kepribadian positif yang ditunjukkan dalam melaksanakan tugasnya. Kompetensi paedagogik yang berhubungan dengan kompetensi guru dalam mengajar secara efektif (Awang dkk, 2013). Kompetensi profesional berkaitan dengan keahlian dalam mengembangkan pembelajaran yang sesuai dengan standar yang telah ditetapkan. Kompetensi sosial berhubungan dengan kompetensi guru dalam berinteraksi sosial dengan masyarakat sekitar.

\section{B. Indikator Kinerja Mengajar IPA}

Peniaian kinerja mengajar guru IPA sangat erat kaitannya dengan penilaian kemampuan dan kompetensi guru dalam mempersiapkan dan melaksanakan kegiatan pembelajaran. Kemampuan tersebut terukur berdasarkan indikator yang sudah dikembangkan baik pada saat mempersiapkan maupun pada saat melaksanakan pembelajaran

Depdiknas (2006) telah menyusun sejumlah indikator dalam mengukur kemampuan dalam mempersiapkan dan melaksanakan pengajaran IPA seperti yang ditunjukkan pada Tabel 1.

\section{Tabel 1. Indikator Kemampuan merencakan pembelajaran}

\begin{tabular}{|c|c|c|}
\hline No & Komponen Kemampuan & Indikator \\
\hline & & Kemampuan Merencanakan \\
\hline \multirow{3}{*}{1} & \multirow{3}{*}{$\begin{array}{l}\text { Perumusan tujuan } \\
\text { pembelajaran }\end{array}$} & Kejelasan rumusan \\
\hline & & Kelengkapan cakupan rumusan \\
\hline & & Kesesuaian dengan kompetensi dasar \\
\hline \multirow{4}{*}{2} & \multirow{4}{*}{$\begin{array}{l}\text { Pemilihan dan } \\
\text { pengorganisasian materi } \\
\text { ajar }\end{array}$} & Kesesuaian dengan tujuan pembelajaran \\
\hline & & Kesesuaian dengan karakteristik peserta didik \\
\hline & & Keruntutan dan sistematika materi \\
\hline & & Kesesuaian materi dengan alokasi waktu \\
\hline \multirow{3}{*}{3} & \multirow{3}{*}{$\begin{array}{l}\text { Pemilihan sumber } \\
\text { belajar/media } \\
\text { pembelajaran }\end{array}$} & $\begin{array}{l}\text { Kesesuaian sumber belajar/media pembelajaran dengan tujuan } \\
\text { pembelajaran }\end{array}$ \\
\hline & & $\begin{array}{l}\text { Kesesuaian sumber belajar/media pembelajaran dengan materi } \\
\text { pembelajaran }\end{array}$ \\
\hline & & $\begin{array}{l}\text { Kesesuaian sumber belajar/media pembelajaran dengan } \\
\text { karakteristik peserta didik }\end{array}$ \\
\hline \multirow{4}{*}{4} & \multirow{4}{*}{ Metode pembelajaran } & $\begin{array}{l}\text { Kesesuaian strategi dan metode pembelajaran dengan tujuan } \\
\text { pengajaran }\end{array}$ \\
\hline & & $\begin{array}{l}\text { Kesesuaian strategi dan metode pembelajaran dengan materi } \\
\text { pembelajaran }\end{array}$ \\
\hline & & $\begin{array}{l}\text { Kesesuaian strategi dan metode pembelajaran dengan } \\
\text { karakteristik peserta didik }\end{array}$ \\
\hline & & Kesesuaian alokasi waktu dengan tahapan pembelajaran \\
\hline \multirow{2}{*}{5} & \multirow{2}{*}{ Penilaian hasil belajar } & Kesesuaian teknik penilaian dengan tujuan pembelajaran \\
\hline & & Kejelasan prosedur penilaian \\
\hline
\end{tabular}




\begin{tabular}{|c|c|c|}
\hline No & Komponen Kemampuan & Indikator \\
\hline & & $\begin{array}{l}\text { Kelengkapan instrumen (soal, kunci jawaban/pedoman } \\
\text { pensekoran) }\end{array}$ \\
\hline \multicolumn{3}{|r|}{ Kemampuan Melaksanakan Pengajaran } \\
\hline \multirow{2}{*}{1} & \multirow{2}{*}{ Prapembelajaran } & Kesiapan ruang, alat pembelajaran, dan media \\
\hline & & Memeriksa kesiapan siswa \\
\hline \multirow[b]{2}{*}{2} & \multirow[b]{2}{*}{ Membuka Pembelajaran } & Melakukan kegiatan apersepsi \\
\hline & & $\begin{array}{l}\text { Menyampaikan kompetensi yang akan dicapai dan rencana } \\
\text { kegiatan }\end{array}$ \\
\hline \multirow{4}{*}{3} & \multirow{4}{*}{$\begin{array}{l}\text { Penguasaan materi } \\
\text { pelajaran }\end{array}$} & Menunjukkan penguasaan materi pembelajaran \\
\hline & & Mengaitkan materi dengan pengetahuan lain yang relevan \\
\hline & & Mengintegrasikan kerja ilmiah dalam pembelajaran \\
\hline & & Mengintegrasikan keterampilan dasar laboratorium*) \\
\hline \multirow{6}{*}{4} & \multirow{6}{*}{$\begin{array}{l}\text { Pendekatan/strategi } \\
\text { pembelajaran }\end{array}$} & $\begin{array}{l}\text { Melaksanakan pembelajaran sesuai dengan kompetensi yang akan } \\
\text { dicapai }\end{array}$ \\
\hline & & Melaksanakan pembelajaran secara runtut \\
\hline & & Menguasai kelas \\
\hline & & Melaksanakan pembelajaran yang bersifat kontekstual \\
\hline & & $\begin{array}{l}\text { Melaksanakan pembelajaran yang memungkinkan tumbuhnya } \\
\text { kebiasaan positif (nurturant effect) }\end{array}$ \\
\hline & & $\begin{array}{l}\text { Melaksanakan pembelajaran sesuai dengan alokasi waktu yang } \\
\text { direncanakan }\end{array}$ \\
\hline \multirow{5}{*}{5} & \multirow{5}{*}{$\begin{array}{l}\text { Pemanfaatan sumber } \\
\text { belajar / media } \\
\text { pembelajaran }\end{array}$} & Menunjukkan keterampilan dalam penggunaan sumber \\
\hline & & belajar/media pembelajaran \\
\hline & & Menghasilkan pesan yang menarik \\
\hline & & Melibatkan siswa dalam pembuatan dan pemanfaatan sumber \\
\hline & & belajar/media pembelajaran \\
\hline \multirow{5}{*}{6} & \multirow{5}{*}{$\begin{array}{l}\text { Pembelajaran yang memicu } \\
\text { dan memelihara } \\
\text { keterlibatan siswa }\end{array}$} & $\begin{array}{l}\text { Menumbuhkan partisipasi aktif siswa melalui interaksi guru, } \\
\text { siswa, sumber belajar }\end{array}$ \\
\hline & & Merespon positif partisipasi siswa \\
\hline & & Menunjukkan sikap terbuka terhadap respons siswa \\
\hline & & Menunjukkan hubungan antarpribadi yang kondusif \\
\hline & & Menumbuhkan keceriaan dan antusisme siswa dalam belajar \\
\hline \multirow{2}{*}{7} & \multirow{2}{*}{$\begin{array}{l}\text { Penilaian proses dan hasil } \\
\text { belajar }\end{array}$} & Memantau kemajuan belajar \\
\hline & & Melakukan penilaian akhir sesuai dengan kompetensi \\
\hline \multirow{3}{*}{8} & \multirow{3}{*}{ Penggunaan bahasa } & Menggunakan bahasa lisan secara jelas dan lancar \\
\hline & & Menggunakan bahasa tulis yang baik dan benar \\
\hline & & Menyampaikan pesan dengan gaya yang sesuai \\
\hline \multirow[b]{2}{*}{9} & \multirow{2}{*}{ Penutup } & $\begin{array}{l}\text { Melakukan refleksi atau membuat rangkuman dengan melibatkan } \\
\text { siswa }\end{array}$ \\
\hline & & $\begin{array}{l}\text { Melaksanakan tindak lanjut dengan memberikan arahan, atau } \\
\text { kegiatan, atau tugas sebagai bagian remidi/pengayaan }\end{array}$ \\
\hline
\end{tabular}

Seiring dengan adanya perkembangan pendidikan di Indonesia, pengembangan kompetensi guru juga mengalami pembaharuan dalam hal kompetensi yang harus dimiliki oleh guru. Peraturan Menteri Pendidikan Nasional No. 16 tahun 2007 tentang kompetensi guru, memuat standar kualifikasi akademik dan kompetensi guru yang dikembangkan secara utuh dari empat kompetensi utama yang dijabarkan menjadi subkompetensi dan indikator yang harus dapat ditunjukkan dan diamati dalam berbagai kegiatan, 
tindakan, dan sikap guru dalam melaksanakan pembelajaran atau pembimbingan seperti yang tercantum pada Tabel 2.

Tabel 2. Kompetensi Guru Mata Pelajaran

\begin{tabular}{|c|c|c|c|}
\hline \multirow{2}{*}{ No } & \multirow{2}{*}{ Ranah Kompetensi } & \multicolumn{2}{|c|}{ Jumlah } \\
\hline & & Kompetensi & Indikator \\
\hline 1 & Pedagogik & 7 & 45 \\
\hline 2 & Kepribadian & 3 & 18 \\
\hline 3 & Sosial & 2 & 6 \\
\hline 4 & Profesional & 2 & 9 \\
\hline & Total & 14 & 78 \\
\hline
\end{tabular}

Secara khusus indikator yang digunakan dalam penilaian kinerja guru IPA dikembangkan pada 14 kompetensi yaitu (1) Memahami konsep konsep, hukum-hukum, dan teori teori IPA serta penerapannya secara fleksibel (2) Memahami proses berpikir IPA dalam mempelajari proses dan gejala alam (3) Mengunakan bahasa simbolik dalam mendeskripsikan proses dan gejala alam (4) Memahami hubungan antar berbagai cabang IPA, dan hubungan IPA dengan matematika dan teknologi (5) Bernalar secara kualitatif maupun kuantitatif tentang proses dan hukum alam sederhana (6) Menerapkan konsep, hukum, dan teori IPA untuk menjelaskan berbagai fenomena alam (7) Menjelaskan penerapan hukum hukum IPA dalam teknologi terutama yang dapat ditemukan dalam kehidupan sehari hari (8) Memahami lingkup dan kedalaman IPA sekolah (9) Kreatif dan inovatif dalam penerapan dan pengembangan IPA (10) Menguasai prinsip prinsip dan teori teori pengelolaan dan keselamatan kerja/ belajar di laboratorium sekolah (11) Menggunakan alat alat ukur,alat peraga, alat hitung, dan piranti lunak komputer untuk meningkatkan pembelajaran IPA di kelas dan di laboratorium (12) Merancang eksperimen IPA untuk keperluan pembelajaran atau penelitian (13) Melaksanakan eksperimen IPA dengan cara yang benar (14) Memahami sejarah perkembangan IPA dan pikiran pikiran yang mendasari perkembangan tersebut.

\section{Ragam Masalah Kinerja Mengajar IPA}

Pada perspektif siswa, dalam pembelajaran IPA masih ditemukan masalah berupa (1) pendidikan IPA masih dianggap sebagai kegiatan didaktik, siswa hampir tidak memiliki kesempatan untuk mengaktualisasi diri terhadap konsep yang mereka miliki, (2) metode-metode yang diterapkan guru kurang mampu memotivasi siswa untuk bertanya, (3) saat siswa memiliki kesempatan untuk menunjukkan kemampuannya dalam mengungkapkan kembali informasi yang diterimanya, seringkali terlihat pemahaman siswa sangat dangkal dan tampak siswa kurang memiliki kemampuan untuk menyelesaikan masalah sesuai dengan kemampuan yang dimilikinya, (4) siswa kurang memiliki kesempatan untuk melakukan kegiatan praktek, hal ini disebabkan oleh strategi yang diterapkan guru serta sarana dan prasarana yang kurang memadai, (5) proses pembelajaran yang dilaksanakan guru cenderung dari "atas ke bawah" bukan dari "bawah ke atas" artinya konsepsi pembelajaran hanya merupakan materi pengetahuan tingkat lanjut yang diturunkan dari disiplin ilmu tertentu bukan sebaliknya yaitu materi-materi yang menyangkut kehidupan sehari-hari, (6) kurang adanya konsep yang terintegrasi dan menyatu antara berbagai disiplin ilmu yang diajarkan, (7) ujian tingkat nasional yang diberikan disamping mempengaruhi apa yang diajarkan juga sangat mempengaruhi bagaimana materi tersebut diajarkan (Blazely dalam Arif, 2001).

Selain itu ditemukan juga permasalahan yang terkait dengan siswa, terdapat juga permasalahan yang dihadapi guru diantaranya yaitu: (1) rendahnya keterampilan guru dalam melaksanakan proses pembelajaran, (2) guru kurang mampu mengaplikasikan keterampilan proses dalam pembelajaran IPA, (3) guru IPA cenderung berfikir tekstual daripada kontekstual, lingkungan dan laboratorium belum digunakan secara optimal sebagai sumber belajar dan kemampuan berfikir tingkat tinggi guru masih lemah dan harus diperbaiki (Sarwanto, 2012) . 
Faktor-faktor penyebab rendahnya kinerja guru IPA ditentukan oleh beberapa hal, diantaranya: (1) dampak lulusan dari berbagai departemen, (2) dampak kurikulum pembelajaran, (3) dampak dari materi pembelajaran, (4) dampak dari lingkungan laboratorium, dan (5) dampak dari asesmen dan evaluasi (Sengul at al, 2008). Selain itu, kurikulum pembelajaran juga mempengaruhi rendahnya kinerja guru, dimana sebagian guru menyampaikan bahwa kurikulum sulit diimplementsikan dalam pembelajaran IPA dan juga kesulitan dalam mempersiapkan materi pelajaran untuk pembelajaran IPA yang efektif.

\section{Pengembangan Instrumen Evaluasi Kinerja Guru IPA}

Penilaian kinerja bagi guru sangat penting dilakukan dalam rangka membentuk guru yang professional. Dalam Buku Pedoman Pelaksanaan Penilaian Kinerja Guru disebutkan beberapa tujuan penilaian kinerja guru, yaitu: (1) menentukan tingkat kompetensi seorang guru, (2) meningkatkan efisiensi dan efektivitas kinerja guru dan sekolah; (3) menyajikan suatu landasan untuk pengambilan keputusan dalam mekanisme penetapan efektif atau kurang efektifnya kinerja guru; (4) menyediakan landasan untuk program pengembangan keprofesian berkelanjutan bagi guru; (5). menjamin bahwa guru melaksanakan tugas dan tanggung-jawabnya serta mempertahankan sikap-sikap yang positif dalam mendukung pembelajaran peserta didik untuk mencapai prestasinya; (6) menyediakan dasar dalam sistem peningkatan promosi dan karir guru serta bentuk penghargaan lainnya (Kemendiknas , 2010).

Tujuh standar yang perlu dipertimbangkan dalam pengembangan instrumen penilaian kinerja menurut Stronge (2012) diantaranya yaitu: (1) Pengetahuan professional, (2) perencanaan pembelajaran, (3) layanan pembelajaran, (4) penilaian pembelajaran, (5) lingkungan belajar, (6) sikap professional, dan (7) perkembangan siswa.

Untuk melaksanakan penilaian kinerja guru yang objektif, akurat, tepat, valid, dan dapat dipertanggungjawabkan diperlukan sejumlah perangkat yang harus dipersiapkan diantaranya adalah: 1) Pedoman Penilaian Kinerja Guru yang mengatur tentang tata cara penilaian dan norma-norma yang harus ditaati oleh penilai, guru yang dinilai, serta unsur lain yang terlibat dalam proses penilaian, saat ini pedoman penilaian kinerja guru di Indonesia dkeluarkan oleh Kementerian Pendidikan dan Kebudayaan. dan 2) Instrumen penilaian kinerja yang relevan dengan tugas guru.

Untuk memudahkan bagaimana melakukan penilaian kinerja guru dan alat apa yang digunakan, perlu dilakukan pemetaan tentang pernyataan kompetensi, indikator dana cara menilainya. Pemetaan tersebut terdapat pada Tabel 3 (Kemendiknas, 2010) dibawah ini :

Tabel 3. Lembar Pernyataan Kompetensi, Indikator, dan Cara Menilai Kinerja Guru

\begin{tabular}{lll}
\hline \multicolumn{1}{c}{ Kompetensi } & \multicolumn{1}{c}{ Cara menilai } \\
\hline Pedagogik & Pengamatan \& Pemantauan \\
\hline 1. & Menguasai karakteristik peserta didik. & Pengamatan \\
\hline 2. & $\begin{array}{l}\text { Menguasasi teori belajar dan prinsip-prinsip } \\
\text { pembelajaran yang mendidik. }\end{array}$ & Pengamatan \\
\hline 3. & Pengembangan kurikulum. & Pengamatan \\
\hline 4. & Kegiatan pembelajaran yang mendidik. & Pengamatan \& Pemantauan \\
\hline 5. & Pengembangan potensi peserta didik. & Pengamatan \\
\hline 6. & Komunikasi dengan peserta didik. & Pengamatan \\
\hline 7. & Penilaian dan evaluasi. & \\
\hline Kepribadian & $\begin{array}{l}\text { Bertindak sesuai dengan norma agama, hukum, sosial, } \\
\text { dan kebudayaan nasional. }\end{array}$ & Pengamatan \& Pemantauan \\
\hline
\end{tabular}




\begin{tabular}{|c|c|}
\hline 9. Menunjukkan pribadi yang dewasa dan teladan. & Pengamatan \& Pemantauan \\
\hline $\begin{array}{l}\text { 10. Etos Kerja, tanggung jawab yang tinggi, rasa bangga } \\
\text { menjadi guru. }\end{array}$ & Pengamatan \& Pemantauan \\
\hline \multicolumn{2}{|l|}{ Sosial } \\
\hline $\begin{array}{l}\text { 11. Bersikap inklusif, bertindak obyektif, serta tidak } \\
\text { diskriminatif. }\end{array}$ & Pengamatan \& Pemantauan \\
\hline $\begin{array}{l}\text { 12. Komunikasi dengan sesama guru, tenaga } \\
\text { kependidikan, orang tua, peserta didik, dan } \\
\text { masyarakat. }\end{array}$ & Pemantauan \\
\hline \multicolumn{2}{|l|}{ Profesional } \\
\hline $\begin{array}{l}\text { 13. Penguasaan materi, struktur, konsep, dan pola pikir } \\
\text { keilmuan yang mendukung mata pelajaran yang } \\
\text { diampu. }\end{array}$ & Pengamatan \\
\hline $\begin{array}{l}\text { 14. Mengembangkan Keprofesionalan melalui tindakan } \\
\text { yang reflektif. }\end{array}$ & Pemantauan \\
\hline
\end{tabular}

\section{E. Gagasan Audit Kinerja-Teaching Audit (IPA)}

Audit adalah evaluasi terhadap orang, organisasi, system, proses, proyek atau produk dengan menggunakan kriteria tertentu, audit dilakukan dalam rangka menentukan validitas dan reliabilitas informasi berdasarkan data-data dan bukti tertentu sehingga dapat memberikaan opini pada masyarakat berdasarkan evaluasi atas pekerjaan berdasarkan pengujian (Soepardi, 2013). Bila audit ini dimplementasikan untuk kinerja pada profesi guru maka akan sifatnya menjadi lebih spesifik.

Setiawan (2012) menyebutkan bahwa audit kinerja guru atau disebut teaching audit adalah suatu proses kegiatan evaluasi/pengujian secara sistematis yang berisi tentang metode dan prosedur audit atas laporan kinerja guru dalam menjalankan tugas profesinya sebagai pendidik dan untuk mendapatkan informasi secara obyektif dalam semua hal yang berhubungan dengan asersi tentang kejadian-kejadian kegiatan kompetensi pendidik (guru) serta menentukan tingkat kesesuaian antara asersi kompetensi tersebut dengan kriteria yang telah ditetapkan dan mengkomunikasikan hasilnya kepada pihak-pihak yang berkepentingan. Tujuan umum audit atas laporan kinerja guru adalah memberikan suatu pernyataan pendapat mengenai apakah laporan kinerja guru yang bersangkutan telah disajikan secara wajar dalam semua hal yang material di dalam melaksanakan tugas profesinya sebagai pendidik sesuai dengan prinsip standar kompetensi profesi pendidik berlaku umum.

Teaching audit terhadap para guru IPA penting untuk dilakukan mengingat mengajar merupakan akuntabilitas publik. Mengajar adalah pekerjaan yang kompleks dan bersifat kontekstual. Ketika mengajar perlu mempertimbangkan karakteristik peserta didik, sumber belajar dan lingkungan belajar. Teaching audit merupakan salah satu bentuk perlindungan terhadap peserta didik dari praktik pengajaran yang tidak bermutu. Satori (2005) menyatakan bahwa audit mutu perlu dilakukan dalam rangka memberikan jawaban apakah penyelenggaraan pendidikan telah memenuhi rambu-rambu, standar ambang, atau kriteria yang ditetapkan.

Pelaksanaan audit dapat melibatkan auditor baik dari dalam ataupun dari luar lembaga. Auditor dari dalam lembaga disebut dengan auditor internal, sedangkan auditor dari luar lembaga di sebut dengan auditor eksternal (Salis, 2010:125). Auditor internal dapat melibatkan kepala sekolah dan juga pengawas, sedangkan auditor eksternal dapat melibatkan auditor eksternal dapat diperankan oleh pendidik profesional (dosen LPTK) atau lembaga yang peduli dengan mutu pembelajaran IPA.

Pelaksanaan audit kinerja guru dilakukan 2 (dua) kali setahun, yaitu pada awal tahun ajaran (penilaian formatif) dan akhir tahun ajaran (penilaian sumatif) (Kemendiknas, 2010). Penilaian kinerja guru secara formatif digunakan untuk menyusun profil kinerja guru dan harus dilaksanakan dalam kurun waktu 6 (enam) minggu di awal tahun ajaran. Sedangkan penilaian guru secara sumatif digunakan untuk 
menetapkan perolahan angka kredit guru pada tahun tersebut, menganalisis kemajuan yang dicapai guru dalam pelaksanaan PKB, baik bagi guru yang nilainya masih di bawah standar, telah mencapai standar, atau melebihi standar kompetensi yang ditetapkan.

Tahap audit kinerja terdiri dari empat tahap, yaitu perencanaan, penerapan, penilaian, dan perbaikan. Semua tahap tersebut dilaksanakan melalui berbagai prosedur yang bervariasi diantaranya: melalui prosedur analitis, inspeksi, konfirmasi, mengajukan pertanyaan, menghitung, menelusur, mencocokkan dengan dokumen, mengamati, melakukan ulang, dan teknik audit berbantuan computer atau computer-assested audit techniques (IAI, 2001).

Data hasil audit kinerja guru akan memberikan manfaat banyak bagi berbagai kalangan. Basri dan Rivai (2005) memaparkan empat manfaat hasil audit kinerja, diantaranya:

a. Performance improvement, yaitu mengenai umpan balik atas kinerja yang bermanfaat bagi karyawan, manajer, supervisor, dan spesialis SDM dalam bentuk kegiatan yang tepat untuk memperbaikikinerja pada waktu yang akan datang.

b. Compensation adjustment, penilaian kinerja membantu dalam pengambilan keputusan siapa yang seharusnya menerima kenaikan pembayaran dalam bentuk upah, bonus ataupun bentuk lainnya yang didasarkan pada suatu sistem tertentu.

c. Placement decision, kegiatan promosi, atau demosi jabatan dapat didasarkan pada kinerja masa lalu dan bersifat antisipatif, seperti dalambentuk penghargaan terhadap karyawanyang memiliki hasil kinerja baik pada tugas-tugas sebelumnya.

d. Training and development needs, kinerja yang buruk mengindikasikan sebuah kebutuhan untuk melakukan pelatihan kembali sehingga setiap karyawan hendaknya selalu memiliki kemampuan untuk mengembangkan diri agar sesuaidengan tuntutan jabatan saat ini.

\section{SIMPULAN}

Penjaminan mutu pendidikan IPA erat kaitannya dengan kinerja guru. Ketika guru IPA melakukan kinerja yang baik maka pelaksanaan pembelajaran IPA sebagai core business Pendidikan IPA dapat dikatakan bermutu. Mutu layanan guru IPA meliputi proses dan hasil pembelajaran. Kinerja merupakan variabel yang digunakan sebagai ukuran tingkat ketercapaian tugas guru. Guru dikatakan memiliki kinerja yang baik manakala dapat menyelesaikan tugas-tugasnya maupun mencapai indikator kinerja guru. Kenyataan tentang masih rendahnya mutu Pendidikan IPA di Indonesia mencerminkan kinerja guru IPA yang perlu untuk ditingkatkan.

\section{DAFTAR PUSTAKA}

Arif. A. (2001). Kajian Pelaksanaan Studi IPA di Jawa Timur. Hasil Penelitian Pengembangan Perangkat Pembelajaran IPA Terpadu di Jawa Timur.

Awang, M. M., Jindal-Snape, D., \& Barber, T. (2013). A documentary analysis of the government's circulars on positive behaviour enbancement strategies. Asian Social Science, Volume 9(5), 203-208.

Bacal, Robert. (2002). Performance Management. Terjemahan Surya Dharma, Yanuar Irawan. Jakarta: Gramedia Pustaka Utama

Basri, A. F. M., dan Rivai, V.(2005). Performance appraisal. Jakarta: PT. Raja. Grafindo Persada.

Depdiknas. (2006). Instrumen Penilaian Kinerja Guru IPA: KemampuanMelaksanakan Pembelajaran Biologi, Fisika, dan Kimia. Jakarta: Depdiknas

Direktorat Tenaga Kependidikan. (2008). Strategi Pembelajaran MIPA. Jakarta: Departemen Pendidikan Nasional Sarwanto. 2012. Refleksi Uji Kompetensi Guru IPA Tahun 2012. Prosiding Seminar Nasional Fisika dan Pendidikan Fisika. Vol 1. No. 4.

Hafi, Muhammad. (2015). Menggugat Kinerja Guru Penerima TPG. Diakses dari http://www.republika.co.id/berita/koran/didaktika/15/08/05/nslnk85-menggugat-kinerja-gurupenerima-tpg. 
Hasibuan, Malayu SP. (2003). Organisasi Dan Motivasi. Jakarta: PT Bumi Aksara.

Hamalik, Oemar. (2001). Proses Belajar Mengajar. Jakarta: Bumi Aksara.

Ikatan Akuntansi Indonesia (IAI). (2001) Standar Profesional Akuntan Publik, Salmba Empat, Jakarta.

Kemendikbud. (2015). Hasil Uji Kompetensi Guru Dijadikan Landasan Program Guru Pembelajar. Diakses dari www.kemendikbud.go.id. [

Kemendikbud. (2015). 7 Provinsi Raih Nilai Terbaik Uji Kompetensi Guru 2015. Diakses dari: www.kemendikbud.go.id.

Kemendiknas (2010). Pedoman Pelaksanaan Penilaian Kinerja Guru. Jakarta: Kemendiknas.

B.1.1 Khalick, Abd-El, Fouad, Dogan, Nihal. (2008). Turkish Grade 10 Students' and Science Teachers' Conceptions of Nature of Science: A National Study. Journal of Research in Science Teaching, 45(10): 10831112.

Koopmans L, et al. (2011). Conceptual frameworks of individual work performance - A systematic review. Journal of Occupational and Environmental Medicine. 2011 08;53(8):856-66.

Mitchell, T. R. \& Larson, J. R., Jr. (1989). People in Organizations: An Introduction to Organizational Behavior. $\left(3^{\text {rd }}\right.$ ed.). New York: McGrawHill

National Science Teacher Associations. (2003). Standards for Science Teacher Preparations. Diakses dari http://www.nsta.org/preservice/docs/NSTAstandards2003.pdf

Notoatmodjo, Soekinjo. DR. (1992). Pengembangan Sumber Daya Manusia. Jakarta : PT Rineka Cipta

OECD. (2012). Assessing Scientific, Reading, and Mathematical Literacy: A Framework, for PIS A 2012. Diakses dari: http: //www.oecd.org/bookshop (9 Oktober 2015)

Peraturan Menteri Pendidikan Nasional Nomor 16 Tahun 2007 tentang Standar Kualifikasi Akademik Dan Kompetensi Guru

Rizal, R. (2018). Implementasi discovery learning dalam meningkatkan pemahaman konsep listrik dinamis. Jurnal Siliwangi: Seri Pendidikan. Vol. 4 No. 1 (2018): 23-27.

Rizal, R. et al (2019). Digital Literacy of Preservice Science Teacher. J. Phys.: Conf. Ser. 1157022058

Rizal, R. (2019). Implementasi Discovery Learning Untuk Meningkatkan Keterampilan Dasar Proses Sains Siswa SMA. JoTaLP: Journal of Teaching and Learning Physics 4, 1 (2019): 01-10

Satori, D. (2005). Supervisi Akademik dan Penjaminan Mutu Dalam Pendidikan Persekolahan. Makalah tidak diterbitkan.

Satori, D. (2012). Supervisi Sebagai Penjaminan Mutu Pendidikan. Makalah tidak diterbitkan

Salis, E. (2010). Total Quality Manajemen in Education [terjemahan]. Jogjakarta: IRCiSoD.

Sarwanto. (2012). Refleksi Uji Kompetensi Guru IPA Tabun 2012. Prosiding Seminar Nasional Fisika dan Pendidikan Fisika. Vol 1. No. 4.

Şengül. S.H., Çetin.G. Gür.H. (2008). The Primary School Science Teacher's Problem's in Science Teaching. Journal of Science Education. Vol. 5. Issue 3 (82-88).

Setiawan. N. (2005). Pengembangan Model Audit Kinerja Guru Dalam Mendukung Program Sertifikasi Pendidik. Diakses dari: http://vikingblack.files.wordpress.com.pdf.

Soepardi. E.M. (2013). Kiat Menjadi Auditor Profesional. Diakses dari: http://www.feunpak.web.id/icfile/ed003.pdf.

Stronge, J.H. (2012). Teacher Effectiveness Performance Evaluation System. Stronge \& Associates.

Undang-Undang Republik Indonesia Nomor 14 Tahun 2005 Tentang Guru Dan Dosen

Usman, Moh. Uzer. (1994). Menjadi Guru Profesional. Bandung : Remaja Rosdakarya. 